\title{
Panic Buying Phenomenon among Academics at X University in Surabaya
}

\author{
Rachma Rizqina Mardhotillah ${ }^{1}$, Denis Fidita Karya ${ }^{2}$, Azmil Chusnaini ${ }^{3}$, \\ Berto Mulia Wibawa ${ }^{4}$ \\ ${ }^{123}$ Universitas Nahdlatul Ulama Surabaya, ${ }^{4}$ Institut Teknologi Sepuluh Nopember \\ e-mail: rachma.rizqina@unusa.ac.id
}

\begin{abstract}
In the weeks at the start of the pandemic, some news in Indonesia was colored related to the panic buying phenomenon by Indonesians in the midst of the Covid-19 pandemic. Of course, the Indonesian people were quite worried about the pandemic at that time. Starting from the scarcity of masks, hand soap and hand sanitizers at the beginning of the soaring positive cases of Covid19 to the scarcity of staple goods consumed by everyday people such as sugar and rice, this phenomenon forced the government to impose restrictions on the purchase of staples. Currently, several regulations have been implemented regarding the purchase of basic commodities by the government to minimize hoarding activities of staple goods. This study aims to see the effect of the Covid-19 pandemic on the emergence of panic buying behavior among the academics of a university in Surabaya. The analytical method used in this research is descriptive analysis with a total sample of 60 respondents consisting of lecturers, students, and educational staff. The research was conducted from June to July 2020. After conducting a survey, it was found that many academics at $X$ University Surabaya were not affected by the panic buying phenomenon.
\end{abstract}

Keywords: Academics, Panic Buying, Covid-19

\section{INTRODUCTION}

The Covid-19 outbreak has had a major impact across the globe. Tourism, education, health, and economies are all affected by this pandemic. One major impact on the economic sector is the emergence of 'panic-buying' (Eva et al., 2020). Panic buying behavior, which means buying with an atmosphere of panic, haste, and uncontrollable, is currently happening in many countries including Indonesia as the spread of the Covid-19 pandemic is getting worse (CNN, 2020). In the midst of the Covid-19 pandemic, anxiety regarding the scarcity of resources, especially food, has increased not only in the middle to lower classes, but also people with high incomes (Putra, 2020). Panic buying is illustrated by the occurrence of a large-scale buying pattern for no clear reason except the fear of not being able to buy something in the future due to the impulse of the current situa- tion. Panic buying can be influenced by other people because of emotional contagion. When the first buyer observes the behavior of the second buyer hoarding groceries, the first buyer may be influenced to do the same. The role of social media, news from TV, radio, and other media which currently preach a lot of panic buying, also indirectly makes people compete to shop. Anxiety is the main factor affecting panic buying. Government regulations related to PSBB (Large-Scale Social Restrictions) also support this panic buying phenomenon. As a result of this regulation, people have flocked to retail stores to fulfill their needs. This step is considered as a precautionary measure against regulations set by the government (Mardhotillah and Rasyid, 2019).

According to Yuen et al. (2020), panic buying behavior is shown when consumers buy products in large quantities in anticipation, dur- 
ing or after a disaster is felt, or to anticipate price increases or shortages of goods. Shadiqi et al. (2020) stated that panic buying behavior is caused by fear, anxiety, feelings of insecurity, psychological conflict, stress, perception of uncertainty, and media exposure. Consumer anxiety during a pandemic shows that there is a public intention to supply sufficient products due to fear and uncertainty. Consumers buy products in large quantities in order to avoid supply shortages that may occur in the future. Research conducted by Nicola et al., (2020) states that the food sector, including food distributors and retail, is under pressure from panic buying. This has led to increasing concerns about shortages of food products. So it can be concluded that the panic buying phenomenon is part of consumer behavior caused by personal (psychological) and environmental factors that influence purchasing decisions (Kaur and Malik, 2020). This study aims to see whether this phenomenon also occurs or is experienced by academics at X University in Surabaya. The academic circles in question are the students, lecturers, and educational staff of X University..

\section{RESEARCH METHODOLOGY}

This research uses descriptive analysis method. The object of this research is the $\mathrm{X}$ university academic community in Surabaya who shopped during the Covid-19 pandemic between March-May 2020 in Surabaya. The sampling technique used is non-probability sampling, because the population cannot be determined (Vehovar et al., 2016). The sampling method is a convenience sampling method based on the ease with which researchers can direct questionnaires with the objects they face. The research data used is primary data derived from questionnaires and interviews with research objects. The questionnaire was distributed to 145 respondents online using the Google Form application and the total sample that can be collected was 125 questionnaires. The questionnaire contains statements according to research indicators and is measured using yes or no answers. Analysis of research data using descriptive analysis.

In this study, there are 25 indicators to be assessed. These indicators were developed from the research that conducted by Widyastuti (2020). The indicators used in this research are:

Table 1 Indicator Table

\begin{tabular}{|c|l|}
\hline No. & \multicolumn{1}{|c|}{ Indicator } \\
\hline 1 & $\begin{array}{l}\text { I bought groceries to anticipate price } \\
\text { increases during the COVID-19 pandemic }\end{array}$ \\
\hline 2 & $\begin{array}{l}\text { I bought groceries products to anticipate } \\
\text { shortages of supplies during the Covid-19 } \\
\text { pandemic }\end{array}$ \\
\hline 3 & $\begin{array}{l}\text { I bought groceries because I saw other } \\
\text { people doing it too }\end{array}$ \\
\hline 4 & $\begin{array}{l}\text { I buy groceries because I am influenced by } \\
\text { the people around me (relatives, friends or } \\
\text { neighbors) }\end{array}$ \\
\hline 5 & $\begin{array}{l}\text { I feel the availability of groceries products } \\
\text { is uncertain during the COVID-19 } \\
\text { pandemic }\end{array}$ \\
\hline 6 & $\begin{array}{l}\text { I bought groceries to meet uncertain needs } \\
\text { during the COVID19 pandemic }\end{array}$ \\
\hline 7 & $\begin{array}{l}\text { I was unable to control the purchase of } \\
\text { groceries products during the COVID-19 } \\
\text { pandemic }\end{array}$ \\
\hline 8 & $\begin{array}{l}\text { I bought groceries because of rumors } \\
\text { (supplies would run out) during the Covid- } \\
19 \text { pandemic }\end{array}$ \\
\hline 9 & $\begin{array}{l}\text { The grocery store that I choose to shop for } \\
\text { offers competitive product prices }\end{array}$ \\
\hline 10 & $\begin{array}{l}\text { I can spend my shopping time at the } \\
\text { grocery store comfortably }\end{array}$ \\
\hline 11 & $\begin{array}{l}\text { The grocery store that I choose to shop } \\
\text { provides clear product information }\end{array}$ \\
\hline 12 & $\begin{array}{l}\text { The grocery store that I choose to shop has } \\
\text { adequate operating hours }\end{array}$ \\
\hline 13 & $\begin{array}{l}\text { The grocery store that I choose to shop has } \\
\text { a strategic location }\end{array}$ \\
\hline
\end{tabular}




\begin{tabular}{|c|l|}
\hline 14 & $\begin{array}{l}\text { The grocery store that I chose to shop } \\
\text { made easy payment transactions }\end{array}$ \\
\hline 15 & $\begin{array}{l}\text { The grocery store that I chose to shop } \\
\text { provided a fast waiting time for payment } \\
\text { transactions }\end{array}$ \\
\hline 16 & $\begin{array}{l}\text { The grocery store that I chose to shop had } \\
\text { a product order that was easy to find }\end{array}$ \\
\hline 17 & $\begin{array}{l}\text { The grocery store that I choose to shop for } \\
\text { has the availability of the products I need }\end{array}$ \\
\hline 18 & $\begin{array}{l}\text { The grocery store that I chose to shop } \\
\text { makes it easy to exchange damaged } \\
\text { products or wrong transactions }\end{array}$ \\
\hline 19 & $\begin{array}{l}\text { The grocery store that I chose to shop } \\
\text { provided guarantees for certain products }\end{array}$ \\
\hline 20 & $\begin{array}{l}\text { I feel determined to buy groceries products } \\
\text { during the Covid19 pandemic }\end{array}$ \\
\hline 21 & $\begin{array}{l}\text { I bought groceries products that I usually } \\
\text { buy (repurchase intention) }\end{array}$ \\
\hline 22 & $\begin{array}{l}\text { I made purchases quickly after choosing } \\
\text { groceries }\end{array}$ \\
\hline 23 & $\begin{array}{l}\text { I buy groceries based on my personal } \\
\text { decision }\end{array}$ \\
\hline 24 & $\begin{array}{l}\text { I buy groceries because I know the } \\
\text { advantages of the product }\end{array}$ \\
\hline 25 & $\begin{array}{l}\text { I bought groceries because I was sure I } \\
\text { needed the product }\end{array}$ \\
\hline
\end{tabular}

\section{RESULT AND DISCUSSION}

Based on the questionnaire that has been distributed to 125 respondents, descriptive data of the respondents are obtained as follows as set out in Table 2.

Table 2 Respondent Descriptive

\begin{tabular}{|l|c|}
\hline \multicolumn{1}{|c|}{ Information } & Percentage \\
\hline Gender & \\
- Male & $37 \%$ \\
- Female & $63 \%$ \\
\hline Profession & \\
- College Student & $5 \%$ \\
- Lecturer & $36 \%$ \\
- Education Staff & \\
\hline Shopping Intensity in a & \\
Month & $42 \%$ \\
- 1-2 Times & $37 \%$ \\
- 3-4 Times & $21 \%$ \\
- >5 Times & \\
\hline
\end{tabular}

\begin{tabular}{|l|l|}
\hline Types of Grocery Stores & \\
Visited & $32 \%$ \\
- Minimarket & $37 \%$ \\
- Supermarket & $5 \%$ \\
- Hypermarket & $0 \%$ \\
- Online & $26 \%$ \\
- All Store Types & \\
\hline Types of Food Products that & \\
are Often Purchased & $58 \%$ \\
- Raw Food & $26 \%$ \\
- Processed Food & $16 \%$ \\
- Ready to Eat Food & \\
\hline
\end{tabular}

Source: Processed Data (2020)

The largest percentage of respondents are female and are dominated by lecturers at $\mathrm{X}$ University. The shopping intensity of the respondents is 1-2 times with the grocery store that is most frequently visited is supermarkets. The types of products that are mostly purchased are raw food ingredients such as meat, chicken or fish.

Based on the results of 125 respondents who filled out the questionnaire, the following indicators were obtained:

Table 3 Questionnaire Result

\begin{tabular}{|l|c|c|}
\hline \multicolumn{1}{|c|}{ Indicator } & Yes & No \\
\hline $\begin{array}{l}\text { I bought groceries to anticipate } \\
\text { price increases during the COVID- } \\
19 \text { pandemic }\end{array}$ & $26 \%$ & $74 \%$ \\
\hline $\begin{array}{l}\text { I bought groceries products to } \\
\text { anticipate shortages of supplies } \\
\text { during the Covid-19 pandemic }\end{array}$ & $42 \%$ & $58 \%$ \\
\hline $\begin{array}{l}\text { I bought groceries because I saw } \\
\text { other people doing it too }\end{array}$ & $11 \%$ & $89 \%$ \\
\hline $\begin{array}{l}\text { I buy groceries because I am } \\
\text { influenced by the people around me } \\
\text { (relatives, friends or neighbors) }\end{array}$ & $21 \%$ & $79 \%$ \\
\hline $\begin{array}{l}\text { I feel the availability of groceries } \\
\text { products is uncertain during the } \\
\text { COVID-19 pandemic }\end{array}$ & $32 \%$ & $68 \%$ \\
\hline $\begin{array}{l}\text { I bought groceries to meet uncertain } \\
\text { needs during the COVID19 } \\
\text { pandemic }\end{array}$ & $26 \%$ & $74 \%$ \\
\hline $\begin{array}{l}\text { I was unable to control the purchase } \\
\text { of groceries products during the } \\
\text { COVID-19 pandemic }\end{array}$ & $11 \%$ & $89 \%$ \\
\hline
\end{tabular}




\begin{tabular}{|l|c|c|}
\hline $\begin{array}{l}\text { I bought groceries because of } \\
\text { rumors (supplies would run out) } \\
\text { during the Covid-19 pandemic }\end{array}$ & $5 \%$ & $95 \%$ \\
\hline $\begin{array}{l}\text { The grocery store that I choose to } \\
\text { shop for offers competitive product } \\
\text { prices }\end{array}$ & $79 \%$ & $21 \%$ \\
\hline $\begin{array}{l}\text { I can spend my shopping time at the } \\
\text { grocery store comfortably }\end{array}$ & $79 \%$ & $21 \%$ \\
\hline $\begin{array}{l}\text { The grocery store that I choose to } \\
\text { shop provides clear product } \\
\text { information }\end{array}$ & $84 \%$ & $16 \%$ \\
\hline $\begin{array}{l}\text { The grocery store that I choose to } \\
\text { shop has adequate operating hours }\end{array}$ & $100 \%$ & $0 \%$ \\
\hline $\begin{array}{l}\text { The grocery store that I choose to } \\
\text { shop has a strategic location }\end{array}$ & $95 \%$ & $5 \%$ \\
\hline $\begin{array}{l}\text { The grocery store that I chose to } \\
\text { shop made easy payment } \\
\text { transactions }\end{array}$ & $100 \%$ & $0 \%$ \\
\hline $\begin{array}{l}\text { The grocery store that I chose to } \\
\text { shop provided a fast waiting time } \\
\text { for payment transactions }\end{array}$ & $79 \%$ & $21 \%$ \\
\hline $\begin{array}{l}\text { The grocery store that I chose to } \\
\text { shop had a product order that was } \\
\text { easy to find }\end{array}$ & $100 \%$ & $0 \%$ \\
\hline $\begin{array}{l}\text { The grocery store that I choose to } \\
\text { shop for has the availability of the } \\
\text { products I need }\end{array}$ & $100 \%$ & $0 \%$ \\
\hline $\begin{array}{l}\text { The grocery store that I chose to } \\
\text { shop makes it easy to exchange } \\
\text { damaged products or wrong } \\
\text { transactions }\end{array}$ & $47 \%$ & $53 \%$ \\
\hline $\begin{array}{l}\text { The grocery store that I chose to } \\
\text { shop provided guarantees for } \\
\text { certain products }\end{array}$ & $32 \%$ & $68 \%$ \\
\hline $\begin{array}{l}\text { I feel determined to buy groceries } \\
\text { products during the Covid19 } \\
\text { pandemic }\end{array}$ & $74 \%$ & $26 \%$ \\
\hline $\begin{array}{l}\text { I bought groceries products that I } \\
\text { usually buy (repurchase intention) }\end{array}$ & $94 \%$ & $6 \%$ \\
\hline $\begin{array}{l}\text { I made purchases quickly after } \\
\text { choosing groceries }\end{array}$ & $74 \%$ & $26 \%$ \\
\hline $\begin{array}{l}\text { I buy groceries based on my } \\
\text { personal decision }\end{array}$ & & \\
\hline $\begin{array}{l}\text { I buy groceries because I know the } \\
\text { advantages of the product }\end{array}$ & $94 \%$ \\
\hline $\begin{array}{l}\text { I bought groceries because I was } \\
\text { sure I needed the product }\end{array}$ & & \\
\hline Sorper & & \\
\hline
\end{tabular}

Source: Processed Data (2020)

From the data above, it was found that most of the X University academic community was not affected by the phenomenon of panic buying behavior, which was often found in the early days of the pandemic. Respondents admitted to purchasing products according to personal decisions, not following other people and not following the current trend.

\section{CONCLUSION}

Consumer purchasing behavior is influenced by many factors, both internally and externally. During the Covid-19 pandemic, consumer decisions in buying products were significantly influenced by anticipatory anxiety if the price of goods increased, influenced by herd or group (Herd Behavior) and instigated media exposure or rumors stating that goods were becoming scarce. However, the purchasing decisions of the respondents in this study are not affected by this phenomenon. They made purchases normally and did not increase significantly when compared to purchases before the pandemic period. Consumers feel that the convenience of payment transactions, convenience benefits and convenience of access are important factors in shopping. Based on the research that has been done, it can be recommended that entrepreneurs or retail managers, especially grocery stores, always prepare themselves for a pandemic. The results of the study prove that people are hit by the panic buying phenomenon when a pandemic occurs. This buying behavior needs to be anticipated by preparing a strategy for more efficient supply chain and inventory management. It is intended that retail stores have sufficient inventory as an anticipatory measure for shortages of goods and rising prices. In terms of management, retail stores need to prioritize customer convenience in various aspects, be it transactions, benefits, accessibility and post-sales service. With increasingly sophisticated technological advances, retail companies 
must be able to adapt and make better use of technology so that consumer convenience is increasing in shopping. For example, the convenience of payment transactions can be done using financial technology to provide consumers with many choices.

\section{REFERENCES}

CNN. 2020. Alasan Psikologi Dibalik "Panicbuying”. https://www.cnnindonesia.com/ gaya-hidup/20200322161747-284-485813/ alasan-psikologi di-balik-panic-buying.

Eva, N., Saputra, D.R., Wulandari, D.A., Yahya, F.A., \& Annisa, W. 2020. Panic-Buying Behaviour during the Covid-19 Outbreak: A Cross-Cultural Psychological Study. KnE Social Sciences, 80-87.

Kaur, A. \& Malik, G. 2020. Understanding the Psychology behind Panic Buying: A Grounded Theory Approach. Global Business Review.

Mardhotillah, R. R. \& Rasyid, R. A. 2019. Pengaruh Kualitas Pelayanan Terhadap Kepuasan Mahasiswa di PTS X Surabaya. Accounting and Management Journal, 3(2), 105-112.

Nicola, M., Alsafi, Z., Sohrabi, C., Kerwan, A., Al-Jabir, A., Iosifidis, C., Agha, M., \&
Agha, R. 2020. The socio-economic implications of the coronavirus and Covid19 pandemic: a review. International Journal of Surgery.

Putra, N.P. 2020. Virus Corona Picu Panic Buying Makanan, Masker, Hand Sanitizer, Bagaimana Meredamnya? https://www. liputan6.com/news/read/4193886/headlinevirus-corona-picu- panic-buying-makananmasker-hand-sanitizer-bagaimana-meredamnya.

Shadiqi, M.A., Hariati, R., Hasan, K.F.A., I'anah, N., \& Al Istiqomah, W. 2020. Panic buying pada pandemi Covid-19: Telaah literatur dari perspektif psikologi. Jurnal Psikologi Sosial.

Vehovar, V., Toepoel, V., \& Steinmetz, S. 2016. Non-probability sampling. The Sage Handbook of Survey Methods, 329-345.

Widyastuti, P. 2020. Analisis Keputusan Pembelian: Fenomena Panic Buying dan Service Convenience (Studi pada Grocery Store di Dki Jakarta), Proceeding SENDIU.

Yuen, K.F., Wang, X., Ma, F., \& Li, K.X., 2020. The psychological causes of panic buying following a health crisis. International Journal of Environmental Research and Public Health, 17(10), p.3513. 